\title{
NUTRITIONAL POTENTIAL OF THE MODIFIED EGGS WITH BIOACTIVE COMPONENTS
}

\author{
Natasha Gjorgovska $^{1}$, Svetlana Grigorova ${ }^{2}$, Desislava Abadjieva ${ }^{3}$, Vesna Levkov ${ }^{1}$, \\ Daniela Belichovska ${ }^{1}$ \\ ${ }^{1}$ Institute of Animal Science, Ss. Cyril and Methodius University in Skopje, \\ Blvd. Ilinden 92a, 1000 Skopje, Republic of North Macedonia \\ ${ }^{2}$ Institute of Animal Science, IAS, 2232 Kostinbrod, Bulgaria \\ ${ }^{3}$ Institute of Biology and Immunology of Reproduction, BAS, \\ Tsarigradsko Shose 73, Sofia, Bulgaria \\ natashagjorgovska@gmail.com
}

\begin{abstract}
A b s t r a c t: The table egg is a product with high nutritive value and digestibility coefficient. Hen egg is an important source of high biological value protein, rich in essential amino acids, vitamins (except vitamin C), minerals and fatty acids. Supplementation of layer diet with increased amount of the healthpromoting bioactive components provide opportunity to produce modified table eggs as functional food with benefits for the human health. Polyphenols, $\beta$-carotene, lycopene, polyunsaturated fatty acids (PUFAs), phytoestrogens, minerals, vitamins and other components are used in the diet for producing functional eggs which are more effective and possess more health-promoting, immunostimulating, therapeutic and functional properties. This minireview describes the concepts of modified eggs with bioactive components, their health benefits and nutritive values.
\end{abstract}

Key words: eggs; health promoting bioactive components

\section{ХРАНЛИВ ПОТЕНЦИЈАЛ НА ЈАЈЦАТА МОДИФИЦИРАНИ СО БИОАКТИВНИ СОСТОЈКИ}

\begin{abstract}
А п с т р а к т: Консумното јајце е производ со висока хранлива вредност и висок коефициент на сварливост. Кокошкиното јајце е важен извор на протеини со висока биолошка вредност, богато со есенцијални аминокиселини, витамини (освен витамин Ц), минерали и масни киселини. Внесувањето во исхраната на кокошките несилки зголемени количини биоактивни компоненти кои го промовираат здравјето, дава можност за производство на модифицирани консумни јајца како функционална храна со придобивки за здравјето на луѓето. Полифеноли, $\beta$-каротен, ликопен, полинезаситени масни киселини (PUFA), фитоестрогени, минерали, витамини и други компоненти се користат во исхраната на кокошките за производство на похранливи јајца, кои имаат повеќе хранливи, имуностимулативни, терапевтски и други корисни својства. Овој краток преглед ги опишува концептите за производство на јајца модифицирани со биоактивни компоненти, нивниот придонес за здравјето и хранливите вредности.
\end{abstract}

Клучни зборови: јајца; здравствено промотивни биоактивни состојки

\section{INTRODUCTION}

Bioactive compounds are defined as components of food that have an impact on physiological or cellular activities in the humans or animals that consume such compounds (Aanchal Walia et al., 2019). They have enzymes that detoxify the body and strengthen the liver, strengthen red blood cells, enhance the immune system, protects from cardiovascular diseases. They create vital sources of nut- 
rients which fight cancer cells, fight infections in the body that lead to inflammation, which in turn leads to fat storage. Bioactive compounds, according to the author, provide a power boost to the thyroid and adrenal glands, empower the genes that turn off fat storage and promote fat burn, reduce premature aging, trigger the body's internal mechanism to eat less, yet have the feeling of being full etc. (Teodoro, 2019). Some of the bioactive food ingredients with beneficial health properties are:

1) polyunsaturated fatty acids,

2) vitamins and minerals,

3) isoflavones and

4) carotenoids.

Eggs are an inexpensive food with high nutritive value, providing 18 vitamins and minerals, with composition which can be affected by several factors such as hen diet, age and strain, as well as environmental factors (Miranda et al., 2015). Polyphenols, $\beta$-carotene, lycopene, PUFA, phytoestrogens, minerals, vitamins and other components are used in the diet for producing functional eggs which are more effective and possess more health-promoting, immunostimulating, therapeutic and functional properties. This minireview describes the concepts of modified eggs with bioactive components, their health benefits and nutritive values.

\section{ENRICHED EGGS WITH PUFA}

Special interest for the dietologists are the alimentary products rich in $\Omega-3$ polyunsaturated fatty acids (PUFAs), first of all $\alpha$-linolenic (ALA, C18:3), eicosapentaenoic (EPA, C20:5) and docosahexaenoic (DHA, C22:6) acids, which are necessary for the brain development, the eye function, prophylaxis of cardiovascular diseases, etc. (Swanson et al., 2012). In most countries in the world, including North Macedonia, $\Omega-3$ fatty acids are deficient in the nutrition. Overall, minimum recommendation is 250-500 mg combined EPA and DHA each day for healthy adults (Mozaffarian and $\mathrm{Wu}, 2012$ ). However, higher amounts are often recommended for cerain health conditions. Laying hens have a limited ability to convert $\alpha$-linolenic acid (ALA) into eicosapentaenoic acid (EPA) and docosahexaenoic acid (DHA) in their organism, and it is recommended these fatty acids to be taken through feed, because in that way the enrichment of eggs with $\Omega$-3 PUFA was more effective (Králík et al., 2007; Škrtić et al., 2007, 2008). Gjorgovska et al. (2018) reported that the best results for increasing the DHA in yolk are reached with supplementation the laying hen's diet with $2.5 \%$ marine alga Schizohitrium sp. (Figure 1). But a dilemma arises: "Why it is better to eat eggs, rather than fish?", because the mackerel, herring, sardines are good source of $\Omega-3$ fatty acids. According to the investigation of Pandey et al. (2005) the eggs are cheaper food than fish $(\$ 2.77-\$ 3.52 / 12$ eggs or $\sim \$ 0.60$ for two eggs), and the exposure of fish to methylmercury and other contaminants as a result of water pollution, could increase their content in fish meat, so the fish may come the source of these contaminants further in the food chain.

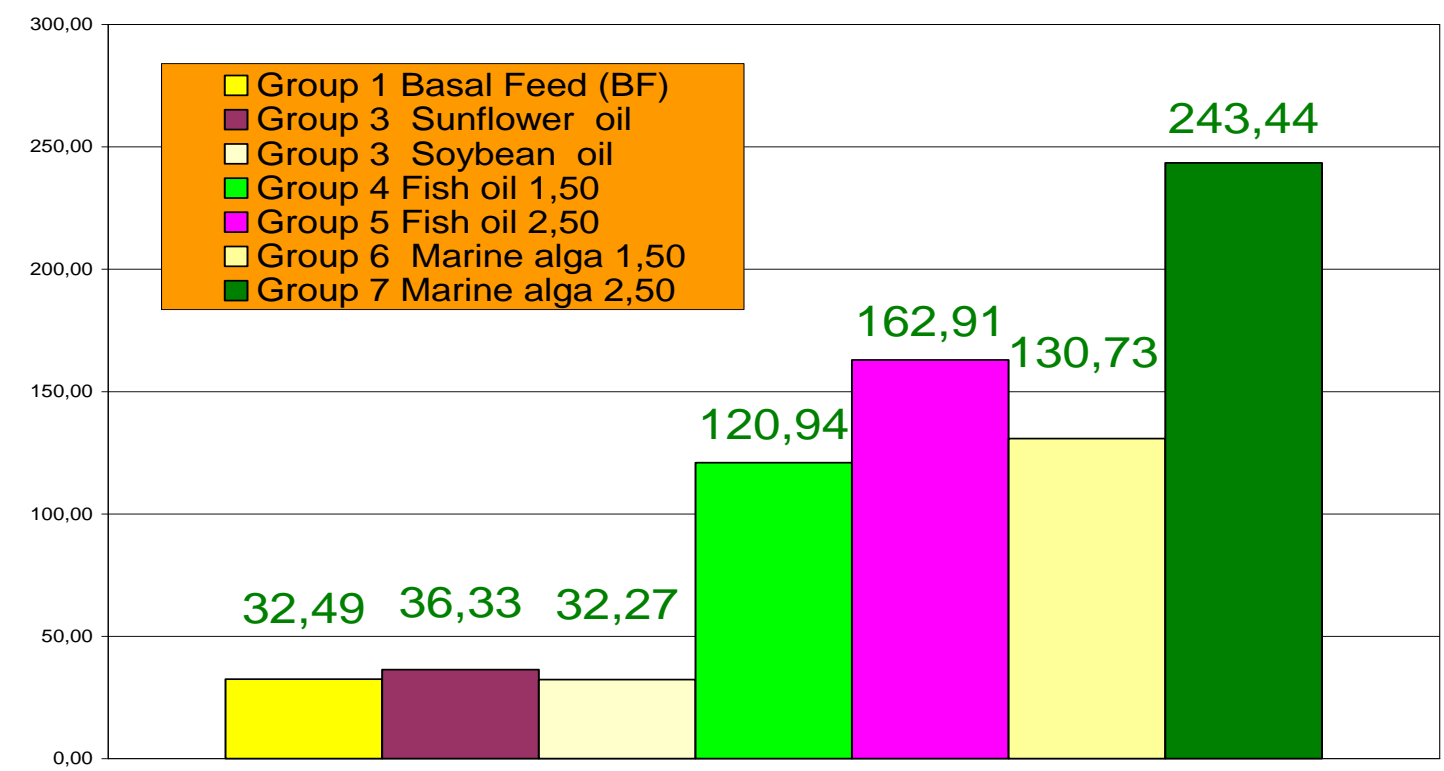

Fig. 1. DHA content in yolk, mg 


\section{ENRICHED EGGS WITH MINERALS AND VITAMINS}

Vitamins and minerals enrichment becomes very important because of antioxidative properties of some of them and essential physiological characteristics important for humans. One of the most important vitamins is vitamin $\mathrm{E}$ because it improves the functionality of the table eggs and their important nutritive value (Meluzzi et al., 2000). Selenium (Se) is recognized as an essential dietary nutrient for almost more than 40 years. It is required for maintenance of health, growth and physiological functi- ons (Rayman, 2000). At the beginning Se has been added to the laying hens' diet via inorganic sources as sodium selenite, but later it has been shown that organic selenium is more bioavailable (Utterback et al., 2005; Gjorgovska et al., 2012). In Table 1 there are represented results for multi-enriched eggs with selenium, vitamin E and DHA and EPA fatty acids (Gjorgovska and Filev, 2011).

The amount of selenium and vitamin E contained in one multi-enriched egg is able to satisfy $10 \%$ and $35 \%$ of the daily human requirements estimated at $45 \mu \mathrm{g} /$ day for Se and $12 \mathrm{mg} /$ day for vita$\min \mathrm{E}$.

Table 1

Enriched eggs with minerals and vitamins (multi-enriched eggs)

\begin{tabular}{lcc|cc}
\hline \hline & & \multicolumn{2}{c}{ Se $0,46 \mathrm{mg} / \mathrm{kg}$} \\
\cline { 2 - 4 } & Vitamin E $100 \mathrm{mg} / \mathrm{kg}$ & $1180 \mathrm{mg} / \mathrm{kg}$ & $792 \mathrm{mg} / \mathrm{kg}$ & $1180 \mathrm{mg} / \mathrm{kg}$ \\
\hline DHA and EPA & $792 \mathrm{mg} / \mathrm{kg}$ & 3.58 & 3.48 & 4.02 \\
Se content in one yolk, $\mu \mathrm{g}$ & 4.14 & 1.91 & 4.55 & 4.01 \\
Vitamin E content in one yolk, $\mathrm{mg}$ & 2.59 & 169 & 139 & 170 \\
DHA and EPA content in one yolk, $\mathrm{mg}$ & 144 & & $\mathrm{mg} / \mathrm{kg}$ \\
\hline \hline
\end{tabular}

\section{ENRICHED EGGS WITH ISOFLAVONES}

Isoflavones have been shown to act as phytoestrogens, to have antioxidant properties and to have a myriad of potential health benefits, and they may also protect the body against breast cancer, heart disease and osteoporosis. These positive results encourage further studies to evaluate the effects of different supplementation levels and strategies for supplementation and enriched the eggs with phytoes- trogens. Feeding laying hens with high concentrations of isoflavones supplemented to feed affected the concentration of genistein and daidzein in the yolk (Gjorgovska and Filev, 2013).

The authors emphasized that in one average yolk, at the end of the experiment, the isoflavone concentration was in the range of 388.4 to $462.0 \mu \mathrm{g}$, (Figure 2) making it a good source of oestrogenlike compounds.

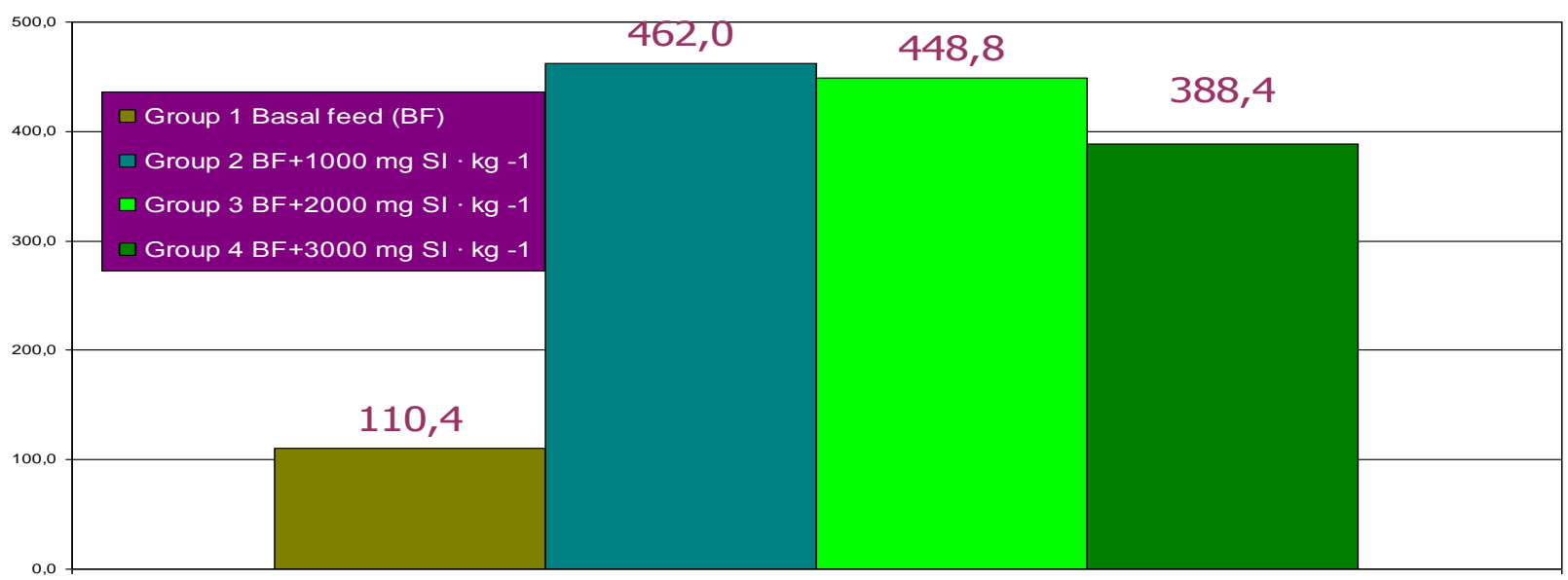

Fig. 2. Isoflavones (genistein and daidzein) content in one average eggs 
Soybean is a good source of oestrogenlike compounds (genistein and daidzein), but currently in USA which is country leader for soy production, 93 percent of the corn and soy is genetically modified in some way (Fernandez-Cornejo et al., 2014). So, these enriched eggs with daidzein and genistein may become a product that is beneficial for menopausal women, and to avoid the usage GMO soybean in nutrition.

Consumption of an omelets meal for lunch could increase satiety to a greater extent than a carbohydrate meal and may facilitate reduction of energy consumption between meals (Pombo-Rodrigues et al., 2011). Overweight premenopausal women who comply with a low-carbohydrate/highprotein diet, self-report less hunger, but similar cognitive eating restraint, over a 6 -week dieting period, compared with women who follow a high-carbohydrate/low-fat diet (Nickols-Richardson et al., 2005).

\section{ENRICHED EGGS WITH CAROTENOIDS}

Carotenoids are important dietary nutrients with health-promoting effects. They represent group of lipid soluble bioactive compounds present in wide variety of food sources. They are particularly abundant in yellow-orange fruits (carrots, tomatoes, pumpkins, peppers) and, although masked by chlorophylls, in dark green leafy vegetables (Xavier and Pérez-Gálvez, 2016). Rosehip (Rosa canina L., fam. Rosaceae) fruits are one of an important source of $B$ carotene (the yellow/orange pigment, which is a precursor of vitamin A) and lycopene (the red pigment); pectin; flavonoids (campferol, quercetin, rutin); potassium, calcium, phosphorus salts (Böhm et al., 2003). The effect of dietary rosehip seed (RS) supplementation into layer diets at different levels was reported by Kaya et al. (2019). Laying hens were fed with basal diet $+10 \%$ ground rosehip seeds (K1) and basal diet $+15 \%$ ground rosehip seeds (K2) for 12 weeks and results showed that rosehip seed supplementation into layer diets may be beneficial to improve egg quality traits especially such as shell thickness and to decrease damaged egg ratio. Skřivan et al. (2015) reported that marigold flower extract in the diet of hens did increase the yolk colour darkness and carotenoid content of the yolk. But further investigations are needed to clarify the use of various plant sources of carotenoids in layer diets and its effects on performance, egg quality and serum parameters, and opportunities for modified eggs enriched with zeaxantin and lutein.

\section{FINAL REMARKS}

The table egg is a product with high nutritive value and digestibility coefficient.

The eggs are ideal products for nutritional modification.

Supplementation of layer diet with increased amount of the health-promoting bioactive components provide opportunity to produce modified table eggs as functional food with benefits for the human health.

These eggs are good source of bioactive components with low price of cost.

Feeding those eggs to animal models or humans confirmed their functional properties, e.g. antiobesity, antiatherogenic and anticarcinogenic effects etc.

New marketing strategies should highlight eggs as an exceptional source of highly bioavailable lutein and zeaxanthin emphasizing their importance in human health.

The importance of eggs as a source of essential nutrients for human nutrition and health has been in creasingly valued and recent research on the enrichment of eggs reinforce its benefits in the reduction of health problems and consequent influence on longevity of consumers.

\section{REFERENCES}

Aanchal Walia, Amit Kumar Gupta and Vatsala Sharma: Role of bioactive compounds in human health. Acta Scientific. Medical Sciences 3. 9, pp. 25-33 (2019).

Böhm, V., Fröhlich, K. and Bitsch, R.: Rosehip - A "new" source of lycopene? Molecular Aspects of Medicine 24, pp. 385-389 (2003).

Fernandez-Cornejo, J., Wechsler, S., Livingston, M., and Mitchell, L.: Genetically engineered crops in the United States. USDA, Economic Research Report, No. 162 (2014).

Gjorgovska, N., Filev, K., Grigorova, S.: Dietary enrichment of eggs with DHA using different sources of fatty acids. Yuzuncu Yal University Journal of Agricultural Sciences, Vol. 28, pp. 164-168 (2018).

Gjorgovska, N., Filev, K., Levkov, V., Kostadinov, T.: The effect of different levels of selenium in feed on egg production, egg quality and selenium content in yolk. Lucrări Ştiintifice, Seria Zootehnie, 57, pp. 270-274 (2012).

Gjorgovska, N., Filev, K.: Multi-enriched eggs with omega 3 fatty acids, vitamin E and selenium. Archiva Zootechnika, Vol. 14, No. 2, pp. 28-35 (2011).

Gjorgovska, N., Filev, K.: Transfer of Daidzein and Genistein from Feed into the Egg Yolk of Hens. Journal of Animal and Feed Sciences, 22, pp. 144-148 (2013). 
Grigorova, S., Surdjiiska S., Banskalieva V., Dimitrov G.: The effect of biomass from green algae of Chlorella genus on the biochemical characteristics of table eggs, Journal of Cenral European Agriculture, 7 (1), pp. 111-116 (2006).

Grigorova, S., Abadjieva, D., Nikolova, M., Penkov, D.: The effect of Tribulus terrestris extract on egg yolk lipids and serum cholesterol content in Guinea fowls, Biotechnology in Animal Husbandry, 25 (5-6), pp. 1109-1115 (2009).

Kaya, H., Kaya, A., Esenbuğa, N. and Macit, M.: The effect of rosehip seed supplementation into laying hens diets on performance, egg quality traits, yolk lipid profile and serum parameters. Alinteri Journal of Agriculture Sciences, 34 (1), pp. 84-87 (2019). DOI: $10.28955 /$ alinterizbd.578536

Králík G., Škrtić Z., Gajčević Z., Hanžek D.: Effect of different oils supplemented to laying hens' diets on the quality of eggs and the fatty acid content in egg yolk (In Croatian). Krmiva 49, pp. 115-125 (2007).

Meluzzi, A., Sirri, F., Manfreda, G., Tallarico, N., Franchini, A.: Effect of dietary vitamin $\mathrm{E}$ on the quality of table eggs enriched with n-3 long chain fatty acids. Poult Sci 79, pp. 539-545 (2000).

Miranda, J. M., Xaquin, A., Redondo-Valbuena, C., RocaSaavedra, P., Rodriguez, J. A., Lamas, A., Franco, C. M., Cepeda, A.: Egg and egg-derived foods: Effects on human health and use as functional foods. Nutrients, 20, 7 (1), pp. 706-29 (2015). DOI: 10.3390/nu7010706

Mozaffarian, D., Wu, J. (n-3) Fatty acids and cardiovascular health: Are effects of EPA and DHA shared or complementary? The Journal of Nutrition Supplement: Vol. 142, Iss. 3, pp. 614S-625S (2012). https://doi.org/10.3945/jn.111.149633

Nickols-Richardson, S. M., Coleman, M. D., Volpe, J. J., Hosig, K. W.: Perceived hunger is lower and weight loss is greater in overweight premenopausal women consuming a low-carbohydrate/high-protein vs high-carbohydrate/lowfat diet. J Am Diet Assoc., 105 (9), pp 1433-7 (2005). DOI: $10.1016 /$ j.jada.2005.06.025.

Pandey, G., Madhuri S., Shrivastav, A. B.: Contamination of mercury in fish and its toxicity to both fish and humans:
An overview. International Research Journal of Pharmacy, 3 (11), pp. 44-47 (2005).

Pombo-Rodrigues S., Calame, W., Re, R.: The effects of consuming eggs for lunch on satiety and subsequent food intake. International Journal of Food Sciences and Nutrition, 62 (6), pp. 593-9 (2011). DOI: 10.3109/09637486.20 11.566212

Rayman, M. P.: The importance of selenium to human health. Lancet, 356 (9225), pp. 233-241 (2000). DOI: 10.1016/S0140-6736(00)02490-9. PMID: 10963212.

Skřivan, M., Englmaierová, M., Skřivanová, E., Bubancová, I.: Increase in lutein and zeaxanthin content in the eggs of hens fed marigold flower extract. Czech Journal of Animal Science 60 (3), pp. 87-96 (2015).

Škrtić, Z., Králík, G., Gajčević, Z., Bogut, I., Hanžek, D.: The increase of the n-3 PUFA content in eggs. Poljoprivreda 13, pp. 47-52 (2007):

Škrtić, Z., Králík, G., Gajčević, Z., Hanžek, D.: Effect of different source of oils on fatty acid profile and organoleptic traits of eggs. Acta Agric Slov. 92, pp. 213-217 (2008).

Swanson, D., Block, R., Mousa, S. A.: Omega-3 fatty acids EPA and DHA: health benefits throughout life. Adv. Nutr. 3, 1, pp. 1-7 (2012). DOI: 10.3945/an.111.000893.

Teodoro, A. J.: Bioactive compounds of food: Their role in the prevention and treatment of diseases, Oxidative Medicine and Cellular Longevity, Vol. 2019, Article ID 3765986, https://doi.org/10.1155/2019/3765986

Odorissi Xavier, A. A., Pérez-Gálvez, A.: Carotenoids as a source of antioxidants in the diet. In: Stange, C. (ed): $\mathrm{Ca}$ rotenoids in Nature. Subcellular Biochemistry, Vol 79 Springer, Cham, 2016. https://doi.org/10.1007/978-3-319$39126-7 \_14$

Utterback, P. L., Parsons, C. M., Yoon I. and Butler J.: Effect of supplementing selenium yeast in diets of laying hens on egg selenium content. Poult. Sci. 84, 1900-1901 (2005).

Fernandez-Cornejo Jorge, Seth Wechsler, Mike Livingston, and Lorraine Mitchell (2014) Genetically Engineered Crops in the United States. Economic Research Service Economic Research Report Number 162 February 2014 
